\title{
Educational context of Berdyaev's personalism
}

\author{
prof. PhDr. Pavol Dancák, PhD. \\ University of Prešov in Prešov, Greek Catholic Theological Faculty
}

Even nowadays, ancient philosophical principle finis est causa causarum reminds that finality plays very important role in the chain of social causality as man has entered into his private and social histories actively, aware of a particular purpose. In education, man always finds himself as a concrete person who verifies theoretical reflexion in life experience as every single educational act presupposes certain vision of purpose, possibly certain ideal final image of the educated one. ${ }^{1}$ Discussions about educational purposes, especially final purposes, present the key topic in philosophy of education. ${ }^{2}$ Among candidates for the last purpose are critical thinking, autonomy, moral responsibility, care and love. These purposes or values play a central role in regulating and arranging of moral and other educational norms, which are far from being only utilitarian reflection of groups' interests of this or that society, but they are also an expression of a human transcendence towards more perfect order of human life. Authentic education, reflecting a phenomenon of transcendence, has always had philosophical dimension, actually "it is the same as philosophism" and shows that purpose of education is not only preparation for some life performances but it is also leading out from every partiality, from every reclusiveness in the sphere of personal restricted interests towards a space opening in the only real human direction, that is the direction from partial to general, to space where man is situated and entitled to live as an individual and as a race. Ján Patočka writes that "true meaning of education is

\footnotetext{
${ }^{1}$ RAJSKÝ, A.: Filozofické aspekty výchovy a vzdelávania. In: KRATOCHVÍLOVÁ, E. (Ed): Úvod do pedagogiky. Trnava : Trnavská univerzita 2007, s. 50.

${ }^{2}$ Porov. HRUŠKKA, D.: Poznámky k výchovnému rozmeru filozofie. Prešov : PU GTF 2009, S. $8-9$.

${ }^{3}$ KRATOCHVÍL, Z.: Výchova, zrejmost, vědomí. Praha : Herrmann \& synové 1995, s. 176.
} 
introduction to the whole of the world..." ${ }^{4}$ Openness to general is also the true openness to all other creatures living together in the world, is the openness to people and things in their true perspective. Here ends the determination of egocentrically directed purposes and occupying of place with a regard to the whole starts.

Wolfgang Brezinka, one of the most important current pedagogic thinkers, tries to describe education as "an attempt for influence, by which we try to reach improvement, betterment or evaluation of the personality of the educated one," whereas according to Radim Palouš, affectionate being together is important - being together with all creatures, with universe, with the whole. ${ }^{6}$ Education is reflected as a dynamic process, which has its own direction, runs from somewhere to elsewhere, from contemporary, bodily-mental-spiritual state of the educated one to a certain assumed, more perfect state that necessarily requires its theoretical reflection which, however, is highly problematic in the area of education, as we are informed by Thaitetos, the author of a dialogue. From the question of how deeply it is possible to study a subject arises another and more important question - to what purpose in life can serve this knowledge, that is, there is a question pointing to purpose of life. Education seems to be impossible without an answer to this question.

Berdyaev's personalism presents precious contribution to the discourse about inner certainty of purpose, towards which education is leading. In his philosophical reflection, human personality materializes in transcendence which is an essential part of human being and which characterizes the whole world of human experience. The world, in which we live our lives, is always restricted but is never closed, is never fixed definitely but it has opened borderlines and it points to itself. "Personality experiences itself as something transcendent, strange to the world and experiences depth of abyss that isolates it from the upper world, from a different world that should be its own. Deep nostalgia is possible in the happiest moments of our lives as well. Man inherently experiences nostalgia for divine life, for purity and for paradise (...) personality is compressed in its endless subjectivity between subjective and transcendent, between objectification and transcendence. It cannot reconcile with commonness of object world, to which it is thrown and is placed in an abyss between subjectivity and objectivity. ${ }^{8}$

\footnotetext{
${ }^{4}$ PATOČKA J.: Aristoteles, jeho predchìdci a dědicové. Praha : ČSAV 1964, s. 370.

${ }^{5}$ BREZINKA, W.: Filozofické základy výchovy. Praha : Zvon 1996, s. 13.

${ }^{6}$ Porov. PALOUŠ, R.: K filozofii výchovy, Praha : SPN 1991, s. 10.

${ }^{7}$ Porov. JAEGER, W.: Paideia II. Warszawa : PAX 1964, s. 96

${ }^{8}$ BERD̃AJEV, N. A.: O otroctví a slobodě člověka. Praha : OIKOYMENH 1997, s. 44.
} 
Personality is not only any general substantial designation, but it is a manifestation of man's uniqueness. Berdyaev does not doubt metaphysical conception of man's substantial unity, but he rather points at limits of such phrasing that limits looking at a person in concrete existential situatedness of subjectivity of man. Therefore it is more fitting for him to talk about man as a personality, as this dimension, including freedom and acting, not only makes man a real man, but it is also a condition for reaching a goal that is in front of him. "Personality may have identical features with others that enable to carry out comparison. But these identical features does not relate to substance which eventually makes a personality from it. [...] In each human personality is something general, universal. In man, there is a good deal of what belong to human kind, historical, traditional, social, class, familiar, good deal of inherited and imitating "general." But exactly all this is not personal in a personality. "Personal" is peculiar, bound to primary, is original. Personality must realize its independent original creative acts, and only what we call personality creates its unique value." 9

Personality flounders in existence suffering from longing for double home. The First home is in paradise home from which it was pulled out and the second homeland is the kingdom of God which is approaching in time. In suffering, it finds courage to progress on a way to longed-for end with difficulty. It relates to something outside itself and stands face to face to the surrounding world that is strange and dangerous, but with which it has created various bonds of need and may also be a kind of place of deification. Even more acutely it realizes that setting out to objectivity is a compromise which leads to subordination to impersonal principles of ascent and social life. Such prevarication from one's own existence usually reaches its peak when man escapes from the anxiety of death. When one escapes from death nostalgia, a sort of latent agony, which one was supposed to put up with throughout a whole life. ${ }^{10}$ Personality is immortal and is aware of being created for eternity. "Death means a decisive experience of breach in the fate of personality, breaking of contact with the world. It does not refer to breaking of its inner existence, but it stands for the end of the existence of a world that was for a personality of another one (...). Personality's setting out towards the fullness of eternity assumes death, catastrophe, jump over an abyss. Therefore is nostalgia indispen-

\footnotetext{
${ }^{9}$ BERĎAJEV, N. A.: O otroctví a slobodě člověka, s. 22.

${ }^{10}$ LETZ, J.: Personalistické metafyziky. Trnava: Veda/Typi universitatis Tyrnaviensis 2006, s. 240.
} 
sable in existence and indispensable is also anxiety from transcendence of eternity." 11

Human personality can reach eternal life only through resurrection and eternal life of Jesus Christ, in whom the connection of man and God is completed. According to Berdyaev, man's immortality by the means of immortal spiritual soul is not secured ontologically. According to him, the existence of immortal soul fully separated from body is a misleading notion derived from Greek metaphysics. Against spiritualistic understanding of a soul, authentic Christianity puts doctrine, or belief, in resurrection of whole man, that is with his changed body. "Immortality may concern only a compact personality in which spirit dominates over psychic and physical part of man. Actually, body belongs to an eternal image of personality and separation of a soul from a body in the process of decomposition of physical part of human, in the loss of body form cannot lead to immortality of a personality that is to a compact human being. ${ }^{12}$

Berdyaev's philosophy has an agogic character with noticeable religious dimension that deals with mission of man to become an authentic man. Strictly speaking, it is a philosophy of freedom that is understandable through the conception of man as personality. The way towards this goal runs through liberation from various determinations that keep man of all times in bondage, in slavery. This existential exodus has individual character for each person. However, it is still possible to determine basic determinants applicable to every man. ${ }^{13}$

Personality presents itself mainly in the categories of freedom and creativity that results from man's spirit, and that is why man cannot join the herd but at the same time he cannot isolate himself individualistically. These two forms of living present temptation of personality that rests on escape from one's own activity.

In the first place, it is about conforming adjustment to a mass, which depersonalize personality and leads man to passivity. Berdyaev calls this way of being a shallow self. "Shallow self of man, very socialized, rationalized, civilized cannot have personalistic dimension, but it even become its deformed image, by the loss of its personality." ${ }^{\prime 4}$ Berdyaev does not refuse civilization, reason or social living but he points to dangers that suppress

\footnotetext{
${ }^{11}$ BERĎAJEV, N. A.: O otroctuí a slobodě člověka, s. 45.

${ }^{12}$ BERĎAJEV, N. A.: O otroctví a slobodě člověka, s. 45.

${ }^{13}$ LETZ, J.: Personalistická filozofia Nikolaja Alexandroviča Berdajeva. s. 39. [15.02.2011] http://www.uski.sk/frm_2009/ran/2004/ran-2004-2-03.pdf

${ }^{14}$ BERĎAJEV, N. A.: O otroctví a slobodě člověka, s. 23.
} 
personality's creativity and freedom. ${ }^{15}$ Another extreme that leads to unauthentic living is the conception of personality as an individual. Berdyaev does not see individual antagonistically but as inseparable part in a relation to the whole, and he therefore suggests distinguishing between individuality and personality. Individuality does not mean independence in relation to the whole, but isolation, any desperate exclusion from the whole. "Man as individual lives isolation, is egocentrically swallowed by himself and he is entitled to fight painfully for life, to defend against lurking dangers." ${ }^{16}$ Fear and violence are born from egocentrism. "Thus antiindividualism arises from individualism as it denies objective reality of individuality and personal objective norm. ${ }^{17}$ In this sense the individual is determined in his own way, either be a slave to the world or to a self, whereas personality proves itself by independence towards surrounding world and therefore only personality is the right individual in a sense of uniqueness, "personality is more individual than the individual."

To alienation of man, to his being plunged to objectified world and to the loss of identity we can get through the way of objectification of personality, by which personality steps out from its subjectivity through science and technology: "It would not be exaggeration to say that the question of technology has become the question of fate of the world and of the culture." 19

Legitimate stepping out of subjectivity, that does not lead to alienation is offered by transcendence, which "refers to transition to transsubjectivity, and not to objectivity. This way runs through the depth of existence where existential meeting with God happens, with another man, with the inner being of the world...." ${ }^{20}$ Human personality is personality only under the condition of non-egocentric relation to the world and this world materializes through inner meeting, which is possible only at existential level of asserting man's freedom which is based on love. Personality affirms itself by opening itself in love. ${ }^{21}$ At this level, Berdyaev tries to show that image of human personality is not only human but it is also divine image. There are hidden all man's mysteries and all secrets. It is the secret of God-

\footnotetext{
${ }^{15}$ Porov. ŠOLTÉS, R.: Chápanie osoby vo filozofii Nikolaja A. Berdajeva. In: DANCÁK, P. HRUŠKA, D. - REMBIERZ, M. - ŠOLÉTS, R. (eds.): Personalizmus a súčasnost' I. Prešov : PU GTF KFR 2010, s. 149-159.

${ }^{16}$ BERĎAJEV, N. A.: O otroctví a slobodě člověka, s. 31.

${ }^{17}$ BERĎAJEV, N. A: Filosofie svobody-piovod zla a smysl dějin. Olomouc : Votobia, 2000, s. 10.

${ }^{18}$ BERĎAJEV, N. A: O otroctví a svobodě člověka, s. 32.

${ }^{19}$ BERĎAJEV, N. A: Človek a stroj. (Problém sociológie a metafyziky techiky). In: Filozofia 1990 , č. 4, s. 430.

${ }^{20}$ BERĎAJEV, N. A: O otroctví a svobodě člověka, s. 26.

${ }^{21}$ PLAŠIENKOVÁ, Z.: Nikolaj Alexandrovič Berdajev (1874 - 1948). In: REMIŠOVÁ, A.: Dejiny etickébo myslenia v Európe a USA. Bratislava : Kalligram 2008, s. 514 - 421.
} 
manhood that presents rationally inexpressible paradox. Personality is a human personality only then when it is a God-manhood personality. ${ }^{22}$

Rational reflexion of human's relation to divinity presents the climax of the Greek educational thinking that was man able to achieve by his own strength. But even this appeal to superhuman origin alone does not necessarily secure right acting of man. Plato's conception of education, culture and civilization, of which "God is the measure of everything" is very agreeable to Christian thinking and tempts to identify its notions with that of Plato. His interpretation is so suggestive that even unchristian thinkers interpret it in a Christian way. Berdyaev noticed that Plato's effort at perfect organization of life hides the danger of totalitarianism. According to Berdyaev, the biggest tragedy for man is objectified God, that is God as anthropomorphic and sociomorphic intellectual concept. "In human ideas of God are reflected human societal and social relationships, relationships of slavery and gentry that has fulfilled human history.....Master-slave relationships have been transferred on a relation of God and man, extracted from societal life. ${ }^{23}$ Through history have been created various images of God, where He has had appearance of a ruler, limitless sovereign and so on. But the True God is God of freedom and love, is the Personality par excellence, is our liberator and not our master in any sense. "He revealed himself not in power but as crucified." 24 "God is freedom and sense, love and sacrifice, is a fight against objectified order of the world."25 God determines nothing and is not to be thought of causally, God does not cause anything. We are face to face to the Secret, and due to this secret it is not possible to use any analogies with necessity, causality and ruling, with the causality of natural phenomena, with ruling, rule as a societal phenomenon. Analogy is possible only with free life of spirit. God is not a cause of world at all.,"26

Berdyaev points to the fact that relation to God cannot be limited with reason, but he requires openness for mystique. Overdone rationalization leads to the deformation of relationship between man and God. Reason is dependent on this world and therefore forces spirit to accommodate. ${ }^{27}$ According to Berdyaev, mystic experience is important for cognition as well as for belief of man. Scienticism is far from being the only and defini-

\footnotetext{
${ }^{22}$ BERĎAJEV, N. A: O otroctví a svobodě člověka, s. 38.

${ }^{23}$ BERĎAJEV, N. A: O otroctví a svobodě člověka, s. 68.

${ }^{24}$ BERĎAJEV, N. A: O otroctví a svobodě člověka, s. 70.

${ }^{25}$ BERĎAJEV, N. A: O otroctví a svobodě člověka, s. 73.

${ }^{26}$ BERĎAJEV, N. A.: O otroctví a slobodě člověka, s. 68.

27 ŠOLTÉS, R.: Chápanie osoby vo filozofii Nikolaja A. Berdajeva. In: DANCÁK, P., HRUŠKA, D., REMBIERZ, M., ŠOLÉTS, R. (Eds.): Personalizmus a súčasnost I. Prešov : PU GTF KFR 2010, s. 149-159.
} 
te criterion of truthfulness. Man approaches cognition of truth through mystic perception, too. ${ }^{28}$ Restricting of cognition solely on rational aspect leads to narrowing of truth's cognition. To Berdyaev is important philosophical synthesis with religious dimension. "The truth liberates but the way to the truth is revealed only through being devoted to the secret of religious life." ${ }^{29}$ Berdyaev emphasizes the role of mystique mainly in theological knowledge, which according to him requires openness for a mystic one. Overdone rationalization of religion always slips to a heresy. That is, heresies always justify everything by reason, even the truths of faith, where there is a space for a secret and trust in loving God, they try to explain it rationally. But this approach has always disguised revelation, from which religion arises. Effort to remove antimonies of faith by reason leads to adjustment of God to human understanding. And therefore there is always "maximum mystique, maximum irrationality and maximum antimony." 30 Transcendent becomes immanent in mystic experience but it is obvious that "immanentism of mystique is entirely different from immanentism in philosophy, in theory of cognition or in theology." ${ }^{31}$ It is living from inside, not from outside. "It is not possible to prove God. It is only possible to come out from God. That means to discover God in one's self primordially." ${ }^{32}$ However, it requires ascetic effort that liberates man from obscurity caused by his own egoism and opens him for a love.

Closer to Berdyaev is apophatic approach to the knowledge of God, in fact, according to him it is not right to create any concept of God, that is, we cannot assign concept to God either, as far as God is completely out of ontological categories. "It is possible to talk about God only in language of spiritual experience symbolism." ${ }^{33}$ All dominant theological teachings - on Christian west or east - are in Berdyaev's view teachings of man's outer spirit which takes away attention from an inner spiritual experience and escapes to the sphere of abstract thinking. And therefore has the abstract absolute similar fate as the highest abstract being that does not differ from nonentity in anything. It does not bring us to the Revelation, it is not possible to pray to it, it is not possible to meet it dramatically. ${ }^{34}$ Such an absolute cannot create the world, and movement and change

\footnotetext{
${ }^{28}$ Porov. BERĎAJEV, N.: Filosofie svobody - filosofie a náboženství. Olomouc : Votobia 2000 , s. 5.

${ }^{29}$ BERD̃AJEV, N. A: Filosofie svobody - filosofie a náboženství,, s. 25.

${ }^{30}$ BERĎAJEV, N. A: Filosofie svobody - filosofie a náboženství, s. 22.

${ }^{31}$ BERĎAJEV, N. A.: Duch a realita. Bratislava : Kalligram 2006, s. 122.

32 BERĎAJEV, N. A: Filosofie svobody - filosofie a náboženství, s. 89.

${ }^{33}$ BERĎAJEV, N. A.: Ríša Ducha a ríša Cisárova. Bratislava : Kalligram, 2003, s. 25.

34 Porov. LETZ, J.: Personalistická filozofia Nikolaja Alexandroviča Berdajeva. s. 41. [15.02.2011] http://www.uski.sk/frm_2009/ran/2004/ran-2004-2-03.pdf
} 
cannot be ascribed to it. Unfortunately, in Christianity also was the image of God deformed and objectified throughought the history."Christianity is not a revelation of God as an absolute monarch, we are protected from it by the revelation the Son of God, sacrificed, suffering, crucified. God is not an absolute monarch. God is a suffering God along with his world and a man, Love and Liberator is crucified." ${ }^{35}$

Starting point from this maze is purging of Christian philosophy and theology from every socioconformism, from every power theocracy. After all, this absolutistic - monarchistic understanding of God brought forth atheism as a protest against this deformation of image of God. ${ }^{36}$ Berdyaev came to the conclusion that: „God is not Providence of the world, that means, the Ruler of the world, the Highest sovereign, Pantokrator, God is freedom and sense, love and sacrifice, is a fight against objectified order of the world (...) Recognition of the world order stands for slavery of man." ${ }^{37}$ Slavish relation to God is in mind and practise expressed by God being absolutized and he is assumed to be everything, whereas man is nothing. Man's peculiarity as well as a possibility of his really free, autonomous creation and his independence from God's determination is underrated. Berdyaev points out that "it is not possible to think that God causes something in this world like powers of nature, that he controls the world and rules in a similar way as kings and authorities in states, that he determines life of the world and man. [...] Mercy is not a power affecting from outside, mercy is a manifestation of the divine in man. ${ }^{38}$ Hence, the relationship of man and God is not "causal relationship, nor the relationship of a tool and a target, not a relationship of master and vassal, it is not similar to anything from objectified world, natural and societal." ${ }^{39}$ So God cannot be only a tool for man as well as man is not a tool for God. God is personality and then "he does not want a man, over whom he would rule and who must celebrate him, he wants a man - personality who answers his challenge, with whom the community of love would be possible. ${ }^{40}$ Man is to be engaged in this love by the means of his freedom. And according to Berdyaev, this is what God expects from a man. „It is not in a way that man calls for freedom from God, on the contrary, God from man, and thanks to this freedom it is obvious that man was created in the image of

\footnotetext{
35 BERĎAJEV, N. A.: O otroctuí a slobodě člověka, s. 70.

36 Porov. LETZ, J.: Personalistická filozofia Nikolaja Alexandroviča Berdajeva. s. 40. [15.02.2011] http://www.uski.sk/frm_2009/ran/2004/ran-2004-2-03.pdf

${ }^{37}$ BERĎAJEV, N. A.: O otroctvi a slobodě člověka, s. 73.

${ }^{38}$ BERĎAJEV, N. A.: Ríša Ducha a ríša Cisárova, s. 30-31.

${ }^{39}$ BERĎAJEV, N.: O otroctví a svobodě člověka, s. 33.

${ }^{40}$ BERĎAJEV, N.: O otroctví a svobodě člověka, s. 34.
} 
God." ${ }^{41}$ Only enslaved man lives in a slavish vision of God and he alone becomes its slave.

Free man is free when he feels and existentially experiences that he is no longer on the periphery of objectified world but he is in the very centre of a spiritual world. Berdyaev reminds that Christianity has brought an optimistic idea of man who in him carries the image of God and teaches about embodiment of God in man. Humanism, as we know it, has Christian origins, as Greco-roman humanism did not assign the highest value and freedom to man. In Greek cosmocentric ideas was man dependent on cosmic forces and in Roman thinking was man completely dependent on a state. Only Christianity is anthropomorphic and liberates man from the power of the universe and society by its essence. ${ }^{42}$

Existential meeting of man and God is the climax, to which man is supposed to grow up to. Only through this meeting can be personality renewed and grow up to life in freedom, what is eventually the condition for humanity alone as well. Only relationship of man and God make man free and independent from determining necessity in all ways. Hence Berdyaev states: „If everybody of us should become a man, the existence of God is necessary as well as the existence of God-man." ${ }^{43}$ Life is impoverished without religious experience freed from false objectification.

In the work The Russian Idea, Berdyaev points out a deep significance of a contrast between terms God-manhood and man-godhood which he found in Dostoevsky. Terminology alone may arouse doubts and requires certain re-examination. Man is supposed to reach deification but this is achievable only through God-man and in God-manhood, what presupposes creative activity of man. Movement does not lead from God to man only but actively from man to God as well. It is a creative movement, creation of the world continues. ${ }^{44}$ "The way of man goes through suffering, cross and death, but does not lead to the resurrection. Only general resurrection of everything living conciliates with the development of the world. Resurrection refers to the victory over time and transformation not only of presence, but of past, too., ${ }^{45}$

Berdyaev's philosophy offers to educational effort personalistic consistent vision of man and society. ${ }^{46}$ It is typical of emphasizing freedom and

\footnotetext{
${ }^{41}$ BERĎAJEV, N.: Ruská idea. Praha : OIKOYMENH, 2003, s. 141.

${ }^{42}$ BERĎAJEV, N. A.: Ruská idea, s. 92-93.

${ }^{43}$ BERĎAJEV, N. A.: Filosofie svobody-piovod zla a smysl dějin, s. 90.

${ }^{44}$ BERĎAJEV, N. A.: Ruská idea, s. 93

${ }^{45}$ BERĎAJEV, N. A.: O otroctví a slobodě člověka, s. 213.

${ }^{46}$ Porov. REMBIERZ, M.: Hermeneutyka ludzkiej egzystencji. Interpretacja Boskiej komedii według Józefa Tischnera, In: MIKOŁAJCZYK, H., OZIĘBŁOWSKI, M., REMBIERZ, M. (eds.): Hermeneutyczne dziedzictwo filozofii. Kraków: Wydawnictwo scriptum, 2006, s. 241-255.
} 
creativity which are derived from man's spiritual naturalness. Everything what is forced on man from outside is a temptation directed against freedom and creativity. ${ }^{47}$ On the one hand, slavish, conformist adaptation or forcing of power, on the other hand, is a manifestation of weakness, immaturity and bondage. Only free personality becomes an icon of God because it is inspired in its freedom by liberating freedom of God. Maiuetic transformation of mind and acts is clearly teleologicaly oriented to the creation of the kingdom of God on this earth in co-creation with godly Personality.

\section{References}

BERĎAJEV, N. A: Človek a stroj. (Problém sociológie a metafyziky techiky). In: Filozofia 1990, č. 4, s. $430-445$.

BERĎAJEV, N. A.: Duch a realita. Bratislava : Kalligram 2006.

BERĎAJEV, N.: Filosofie svobody-filosofie a náboženství. Olomouc : Votobia 2000.

BERĎAJEV, N. A: Filosofie svobody-piovod zla a smysl dějin. Olomouc : Votobia, 2000.

BERĎAJEV, N. A.: O otroctvi a slobodě člověka. Praha : OIKOYMENH 1997. BERĎAJEV, N. A.: Ríša Ducha a ríša Cisárova. Bratislava : Kalligram, 2003. BERĎAJEV, N.: Ruská idea. Praha : OIKOYMENH, 2003.

BREZINKA, W.: Filozofické základy výchovy. Praha : Zvon 1996.

DUDA, K.: Symboliczna przestrzeň twórczości w myśli Mykołaja Bierdiajewa. In: DUDA, K., OBOLEVITCH, T. (Eds.): Symbol w kulturze rosyjskiej. Kraków : WSFP Ignatianum/ WAM 2010, s. 179 - 191.

HRUŠKA, D.: Poznámky k výchovnému rozmeru filozofie. Prešov : PU GTF 2009.

JAEGER, W.: Paideia II. Warszawa : PAX 1964.

KRATOCHVÍL, Z.: Výchova, zrejmost, vědomí. Praha : Herrmann \& synové 1995.

LETZ, J.: Personalistické metafyziky. Trnava: Veda/Typi universitatis Tyrnaviensis 2006.

LETZ, J.: Personalistická filozofia Nikolaja Alexandroviča Berdajeva.

[15.02.2011] http://www.uski.sk/frm_2009/ran/2004/ran-2004-2-03.pdf

PALOUŠ, R.: Kfilozofii výchovy, Praha : SPN 1991.

PATOČKA J.: Aristoteles, jeho předchuidci a dědicové. Praha : ČSAV 1964.

${ }^{47}$ Porov. DUDA, K.: Symboliczna przestrzeň twórczości w myśli Mykołaja Bierdiajewa. In: DUDA, K., OBOLEVITCH, T. (Eds.): Symbol w kulturze rosyjskiej. Kraków : WSFP Ignatianum/WAM 2010, s. 179 - 191. 
PLAŠIENKOVÁ, Z.: Nikolaj Alexandrovič Berdajev (1874 - 1948). In: REMIŠOVÁ, A.: Dejiny etickébo myslenia v Európe a USA. Bratislava : Kalligram 2008, s. $514-421$.

RAJSKÝ, A.: Filozofické aspekty výchovy a vzdelávania. In: KRATOCHVÍLOVÁ, E. (Ed): Úvod do pedagogiky. Trnava : Trnavská univerzita 2007, s. 49-55.

REMBIERZ, M.: Hermeneutyka ludzkiej egzystencji. Interpretacja Boskiej komedii według Józefa Tischnera, In: MIKOŁAJCZYK, H., OZIEBŁOWSKI, M., REMBIERZ, M. (eds.): Hermeneutyczne dziedzictwo filozofii. Kraków: Wydawnictwo scriptum, 2006, s. 241-255.

ŠOLTÉS, R.: Chápanie osoby vo filozofii Nikolaja A. Berdajeva. In: DANCÁK, P. - HRUŠKA, D. - REMBIERZ, M. - ŠOLÉTS, R. (eds.): Personalizmus a súčasnost' I. Prešov : PU GTF KFR 2010, s. 149-159. 